\title{
The Depublication Practice of the California Supreme Court
}

\author{
Joseph R. Grodin $\dagger$
}

On increasingly numerous occasions since 1971, the California Supreine Court has ordered that certain opinions of the court of appeal be "depublisled," that is, not printed in the Official Reports. ${ }^{1}$ This occurs even though the lower court deems the opinion to meet the applicable criteria for publication. ${ }^{2}$ And, I think it is fair to say, the supreme court has not done this, in the vast majority of such occasions, because it disagrees with the court of appeal over application of the criteria. Rather, it has done this because a majority of the justices con-

$\dagger$ Associate Justice of the California Supreme Court.

1. Depublication is authorized by the California Constitution, article VI, $\S 14$, which provides that "[t]he Legislature shall provide for the prompt publication of such opinions of the Supreme Court and courts of appeal as the Supreme Court deems appropriate . . . " That authority is implemented through rule 976(c)(2) of the California Rules of Court, which provides that "[a]n opinion certified for publication shall not be published, and an opinion not so certificd shall be published, on an order of the Supreme Court to that effect." The term "depublieation" is commonly used interchangeably with "decertification," the term derived from the language of the Rules of Court.

No existing rule establishes the criteria for depublication or the process by which opinions are depublished. However, one commentator has identified three procedures the supreme court has used to decertify opinions. The first and most typical is for one of the litigants in the case to file a petition for hearing with the supreme court after the court of appeal's opinion has been certified for publication. Note, Decertificalion of Appellate Opinions: The Need for Articulated Itudicial Reasoning and Certain Precedent in California Law, 50 S. CAL. L. Rev. 1181, 1186 (1977). The supreme court, instead of hearing the case or simply denying the petition, orders the opinion decertified. Id. at 1200 . The second procedure, very rarely used, is for interested parties to write to the supreine court requesting depublication, no petition for hearing having been filed. $/ d$. at 1186. The third procedure, also rarely used, is for the supreme court to act on its own to decertify an opinion. Id.

According to unofficial tally, the supreme court ordered depublication of 20 cases in 1972, 22 in 1973, 12 in 1974, 45 in 1975, 34 in 1977, and 35 in 1978. Id. at 1200-06; Biggs, Censoring the Law in California: Decertification Revisited, 30 HAStings L.J. 1577, 1594-96 (1979).

2. The applicable criteria for publication are set forth as follows:

No opinion of a Court of Appeal . . . may be published in the Official Reports unless the opinion:

(1) establishes a new rule of law, applies an existing rule to a set of facts significantly different from those stated in published opinions, or modifies, or criticizes with reasons given, an existing rule;

(2) resolves or creates an apparent confiict in the law;

(3) involves a legal issue of continumg public interest; or

(4) makes a significant contribution to legal hiterature by reviewing either the development of a common law rule or the legislative or judicial history of a provision of a constitution, statute, or other written law.

CAL. CT. R. 976(b). 
sider the opinion to be wrong in some significant way, such that it would mislead the bench and bar if it remained as citable precedent. ${ }^{3}$ It seems to have been the dominant view within the court that the selective exercise of the depublication option is both practical and proper.

From outside the court, however, the perspective is different. When I was a court of appeal justice, I viewed with disnray the prospect that one of my own hardwrought masterpieces might thus be doomed to obhivion. Persons outside the judiciary have expressed more substantial concerns, throughout which I sense a strong undercurrent of feeling that goes beyond any specific defect in the depublication process. The feeling is that depublication is somehow egregious per sethat it smacks of an attempt to rewrite history, to censor the expression of views, and perhaps even to carry out some secret agenda known only to the court. ${ }^{4}$ While this attitude may appear quite unfounded to those directly familiar with the process, it is nonetheless a widespread perception and one that should not be ignored.

In light of the opposition to depublication that has been expressed, then, it seems appropriate for a member of the court to explain from his perspective the reasons for the practice and its continuance. At the risk of being considered foolhardy in the extreine, I undertake that task. Depublication is best considered, I suggest, in three stages. First, in order to put the process of depublication in context, it is necessary to describe how the court functions. Second, depublication should be compared to other methods the court uses to dispose of cases. Third, alternatives, such as depublication with cominentary and denial with cominentary, as well as different forms of grant options, should be evaluated.

\section{I}

\section{DePublication IN CONTEXT}

Adequate understanding of the depublication practice requires some knowledge of low the court internally handles its caseload. Various descriptions of the internal procedures of the court have appeared

3. See Note, supra note 1, at 1185 n.20 (quoting letter from California's former Chief Justice Wright).

4. For example, a recent article by Professor Gerstein attacks depublication as a "process of covert substantive review." Gerstem, "Law by elimination:" depublication in the California Supreme Court, 67 JUDICATURE 292, 298 (1984). A leading newspaper, in an editorial entitled Lawmaking by Suppression, suggests that the court uses depublication as a "form of damage control whicls enables the justices to bring about what they regard as the right result witl a mininum of adverse publicity." Sacramento Bee, Feb. 27, 1984, at B6, col. 1, B6, col. 2. It is ironic that the Bee's editorial author charges the court with using depublication of determinate sentence cases to promote shorter sentences, while we are just as roundly criticized by another commentator for using depublication of two determinate sentence cases to permit longer sentences. See Yegan, Depublication: The Missing Determinate Sentence Law Opinions, L.A. LAw., Apr. 1982, at 34, 37. 
in print heretofore. ${ }^{5}$ However, it may be useful to set forth my perspective of those procedures, to place my evaluation of the depublication practice in context. It will then become apparent which cases are best handled by depublication. This description will also demonstrate the extent to which the court is overburdened, partially explaining its need to use the depublication procedure.

\section{A. The Supreme Court's Workload}

The work of the supreme court revolves around two focal points. One is the monthly "calendar," the focal point of the court's decisional process. Calendar consists of from two to five days of oral argument once a month during ten months of the year. When the court grants a petition for hearing $\mathrm{m}$ a case, or issues an alternative writ in an original proceeding, the Chief Justice assigns the case to one of the justices for preparation of a "calendar memorandum." A memorandum analyzes the issues and arguments presented, and recominends a disposition. Copies of the memorandum on a particular case are distributed to each justice prior to oral argument. Innmediately after oral argument, the justices confer on the case and take a tentative vote. If it appears that a majority of the justices agree with the disposition recoinınended by the memorandum, the author of the memorandum usually proceeds to draft a proposed majority opinion. Otherwise, the Chief Justice reassigns the case to a justice in the majority.

When the opinion is drafted, copies are distributed to all the justices simultaneously. The origmal of the proposed opinion, together with accompanying materials ("the box") is sent first to whichever justice voiced a differing view at conference, for the possible preparation of a dissenting or concurring opinion. If such an opinion is filed, the majority author is given an opportunity to respond, and thereafter the box is circulated to each remaining justice for his or her signature on one of the circulating opinions, or for the preparation of an additional opinion, as he or she sees fit. Only when each justice has signed an opimion and the authors of the opinions have given their approval are the opimions formally filed.

All justices are of course continuously involved in the decisional process, preparing for and participating im oral argument, drafting or revising their own opinions, making suggestions, or preparing responses to the opinions of others. At any one moment there may be as many as fifty boxes in circulation, and an imdividual justice may have

5. See, e.g., Goodman \& Seaton, Foreword: Ripe for Decision, Internal Workings and Current Concerns of the California Supreme Court, 62 CALIF. L. REv. 309, 309-16 (1974); Traynor, Some Open Questions on the Work of State Appellate Courts, 24 U. CHI. L. REv. 211, 214-17 (1957). 
several boxes in his or her chambers, awaiting action. A justice may find it impossible because of the pressure of other priorities to give a case the immediate attention it deserves. Thus he or she may "pass" the box to another justice, deferring his or her own consideration to a later date. The process can at times be lengthy, particularly when a justice raises new questions or objections that can only be answered by further research or checking of the record. Nonetheless, the process both permits and encourages all justices to give careful attention to the arguments of the parties and to one another's views.

The second focal point of the justices' work is the screening process, which revolves around the Wednesday conference. Each Wednesday throughout the year, except for calendar weeks and the first week m July and August, the court meets in the chambers of the Chief Justice. There, we consider and take action upon petitions for hearing, for extraordinary writs, and for a variety of other petitions and motions, mcluding State Bar disciplinary matters. On each of these matters a conference memorandum has been preparcd, either by the attorneys in the court's central staff (who handle most criminal conference inemoranda) or by a justice to whom the matter has been assigned in rotational order, and his or her staff.

Whoever is responsible for preparation of the conference ineinoranduin assigns it to either the "A-list" or the "B-list." The former consists of those matters that appear more significant or controversial, and therefore more appropriate for conference discussion. The latter consists of those matters that require little discussion, as denial of the petition or motion appears to be clearly indicated. The assignment is tentative, however, for often a justice will request that a B-list matter be continued for discussion as an A-list nuatter at a later date.

Subject to such requests, the court at conference approves the demal recommendations on the B-hist niatters, and proceeds to discuss each item on the A-list. First, the justice responsible for the niemorandum sets forth his or her views. Then, each justice in turn, beginnimg with the most senior and ending with the Chief Justice, is given an opportunity to comment and vote. Some itens on the agenda are disposed of very quickly -in a mimute or two-while others require extensive discussion. Ultimately, four votes are required for any disposition. ${ }^{6}$

The volume of iteins on the Wednesday agenda has become increasingly impressive. Not many years ago, it was rare for the agenda to include inore than twenty or twenty-five items. ${ }^{7}$ Now, it is rare for

6. See Mosk, The Supreme Court of California, 1973-1974 Foreword: The Rule of Four in California, 63 CALIF. L. REv. 2 (1975).

7. In the early 1960 's the total annual filings in the court fell to somewhere between 1300 
the agenda to include fewer than 100 , and in conferences after a skipped week, such as calendar week, the agenda often exceeds 170. Typically, about two-thirds of these items are B-listed, but the petitions and memoranda have to be read and considered nevertheless. The job is not one for a slow reader. 8

While each justice has a distinctive approach in preparing for conference, mine is probably typical. As each agenda itein is received in my chambers, it is assigned to a nember of my staff. A inemorandum is prepared, with varying degrees of consultation on my part regarding its contents and recommendation, and is then submitted to ine for approval. After I have approved, the inemorandum is duplicated and distributed to all justices. The deadline for submission to the secretary's office, to permit timely duplication and distribution, is four o'clock of the Thursday afternoon before conference.

Friday afternoon, I receive the petitions and memoranda from the other justices and the court's central staff. These I take with ine over the weekend to read, inaking note of the cases that seein to me to require further research or discussion. Monday mornimg, I circulate among iny staff a list of cases, with individual assignments to members of my staff, requesting either a brief suppleinental meinorandum or elaboration at staff conference. Tuesday afternoon, 1 ineet with my staff and discuss the more challenging cases. Tuesday evening, I take houne for review the petitions and ineinoranda in my "own" cases, as well as any other cases that seein to require further study. Conference begins at 9:15 the following inorning.

\section{B. Disposition of Petitions for Hearing}

There are various options available to the court when its jurisdiction is mvoked by a petition for hearing or original petition for extraordinary writ. One option, of course, is for the court to grant the petition and keep the case for decision. ${ }^{9}$ Certainly the court ought not grant a hearing simply because the court of appeal has written an opimion with which the supreme court disagrees, nor should such disagree-

and 1600. By the mid-1960's, the numbers had begun to climb rapidly. 1966 Jud. CounCiL CAL. ANN. REP. 11-12; see also P. STOLz, JuDGING JUDGEs 194 (1981) (approximately 40 matters arose per weck in 1964, while only 20 arose per week in 1945).

8. Clearly the impact of this increase in the number of petitions filed is that "a substantial amount of time must be spent by our highest Court not in deciding cases, but rather in deciding not to decide them." Report of the Special Committee re Appellate Courts, The Court of Review: A New Court for California?, 47 CAL. ST. B.J. 28, 29 (1972).

9. The absolute number of petitions granted has risen steadily over the last decade. In 1972-73 the court granted 181 petitions, while by 1981-82 that number had risen to 280 . Because of the steady rise in petitions filed during the same period, however, the percentage of grants relative to the total number of petitions filed rose much less dramatically from $7.6 \%$ in $1972-73$ to 8.3\% in 1981-82. 1983 Jud. CounCIL CAL. ANN. REP. 81, table iv. 
ment be prerequisite to a grant. Rather, the grant option is reserved for those "important" cases appearing to require supreme court guidance. ${ }^{10}$ Given the considerable limitations upon the court's time and resources described above, and taking into account the burden of automatic appeals in death penalty cases ${ }^{11}$ and state bar disciplinary matters, ${ }^{12}$ the option to grant is not one that ought to be, or indeed can be, exercised lightly. ${ }^{13}$

A second option open to the court is to grant the petition and loold the case pending disposition of some other case that is awaiting decision by the court. Once the related case has been decided, the held case can be retransferred to the court of appeal for decision. ${ }^{14}$ Obviously, the "grant and loold" option makes sense only when there is another case pending before the court that involves the same or similar issues. Even then a grant and hold is not always warranted. For example, if the petitioner is seeking review of a trial court order prior to the trial, and the issue will be reviewable upon appeal or habeas corpus, the court may be reluctant to delay trial of the case until the related case is

10. California Rule of Court 29(a) provides:

A hearing in the Supreme Court after decision by a Court of Appeal will be ordered

(1) where it appears necessary to secure uniformity of decision or the settlement of iinportant questions of law; (2) where the Court of Appeal was without jurisdiction of the cause; or (3) where, because of disqualification or other reason, the decision of the Court of Appeal lacks the concurrence of the required majority of qualified judges.

11. As of this writing, 150 death penalty appeals are pending before the court. Most are not yet in a posture for decision. These appeals are automatic and are "pending" once the trial court's commitment is received by the clerk. However, many inonths will pass before the reporter's transcript is certified, the record is forwarded to this court, and both appellant and respondent have fully briefed the appeal. Only then can the court prepare a calendar meinoranduin and set the case for oral argument and decision.

Chief Justice Bird and the court have undertaken a nunber of steps in recent years to deal more effectively with death penalty appeals. Additional law clerks have been added, atteinpts have been made to expedite preparation of transcripts by court reporters, meetings have been held with the death penalty coordmators from the Attorney General's and Public Defender's Offices, and systems have been instituted for identifying and coordinating dispositive common issues. Nevertheless, the burden remains substantial.

The automatic appeal burden has prompted several reform proposals, including suggestions for consideration in the first instance of death penalty cases by the court of appeal, or by a specialized internediate court with statewide jurisdiction. From the perspective of an overworked supreme court justice, the proposals appear quite attractive, but they obviously require careful scrutiny in terms of constitutional requirements and the adininistration of justice.

12. See Coinnent, Attorney Discipline and the California Supreme Court: Transfer of Direct Review to the Courts of Appeal, 72 CALIF. L. REv. 252 (1984).

13. From time to time it is suggested, usually by someone outside the court, that the workload each justice can handle could be increased if greater responsibility was delegated to his or her staff. That is a inatter, of course, that each justice must evaluate personally. In my case, while 1 ain blessed with an extremely competent and experienced staff, I doubt that I could delegate responsibility further to any significant extent and still perform what I consider to be my constitutional obligation.

14. See Comnent, Case Dispositions by the California Supreme Court: Proposed Alternatives, 67 CALIF. L. Rev. 788, 802-03 (1979). 
dccided. Or, the court of appeal may have reached a result consonant with the view expressed in the circulating majority opinion in the case pending before the supreme court. In such a case there may be no need for a grant and hold unless the court wishes to avoid anticipating the probable outcome.

A third option for disposition arises when there is no opinion in the court of appeal, as in the case of an extraordinary writ petition that the court of appeal summarily denied, and the supreme court is of the view that the matter warrants more complete appellate attention. The court will usually grant the petition for hearing, and at the same time retransfer the case to the court of appeal with directions to issue an alternative writ. If there has been an appellate opinion, the "grant and retransfer" option typically is used only when the retransfer can be accompanned by an "in hight of" citation to a case subsequently decideda rare situation. Seldom has the court ordered reconsideration of an appellate opinion that cites applicable authority but reaches the "wrong" result. ${ }^{15}$

What should the court do when it considers a court of appeal opinion to be "wrong," but the circumstances do not warrant either a grant or grant and retransfer under existing practice and applicable criteria? One answer might be simply to deny hearing, and hope that the error will not be too seriously compounded before another court of appeal gets around to setting things straight. That is, in fact, what the court often does. In some situations, however, the risk of compounding the error appears quite substantial-as when permitting the appellate opinion to stand as citable precedent may result in building ultimately reversible error into a large number of trials. It is in such situations, typically, that the court resorts to the decertification option.

\section{II Criticisms of the Depublication Procedure}

\section{A. Criticisms Enumerated}

Despite its usefulness as an option available to the supreme court for the disposition of petitions for hearing, depublication has been criticized from many angles. For example, one commentator found decertification to be a "valuable procedure, which should be retained if it can be properly regulated," 16 but identified "three major failings" in

15. The retransfer "in light of" option is analogous to an order by the United States Supreme Court granting, vacating, and remanding "for further consideration in light of" some more recent Supreine Court decision. Use of "in light of" remands by the United States Supreme Court has proven confusing to at least one commentator. See Hellman, "Granted, vacased, and remanded"-shedding light on a dark corner of Supreme Court practice, 67 JUDICATURE 389 (1984).

16. Note, supra note 1, at 1199. 
current practice. ${ }^{17}$ First, the author contended, the practice "fails to comport with established standards of public exposure of judicial acts because the decertification order fails to set forth the reasoning of the supreme court," 18 thus leaving the litigants and the public without guidance as to the applicable law. Second,

[s]ince no specific procedure has been developed to allow public notice of petitions for decertification that the supreme court receives, the court may hear arguments from one sector of the legal community and act upon them before other imterest groups can present their arguinents or learn of the need to submit their views. ${ }^{19}$

This state of affairs, the autlor contended, may permit "special interest groups" to influence decertification decisions. ${ }^{20}$ Finally, the author argued that "[d]ecertification creates uncertainty in the law for brief but discernible periods of time because it follows publication of appellate opimions in the advance sheets of the Official Reports," thus permitting reliance upon the opinion as precedent before it becomes depublished. ${ }^{21}$

Another criticism is that msofar as depublication implies supreme court disapproval of the opimion below, the depublication order deprives the losing party below of its riglit to a reasoned judgement-or in this view worse still, it imphes that the judgınent itself was wrong. ${ }^{22}$

\section{B. Criticisms Discussed}

\section{Lack of Guidance}

When the court orders an appellate opinion depublislied, its reason for doing so may on some occasions be fairly clear. For example, two related appellate opinions may reach the supreine court at about the same time, and the court may deny hearing in both but leave only one published. However, in many, if not most situations, the reason for the depublication order is not apparent. To that extent the critics are quite correct: the order leaves the parties and the public without guidance both as to why the order was entered, and as to what reasoning backed the imphicit determination that the opinion was im some respect incorrect.

That, it must be conceded, is liardly an ideal state of affairs. Whether it is better or worse on balance than the alternative of letting the published opimion stand is another inatter. While depublication

17. Id. at 1187 .

18. Id.

19. Id. at 1190 .

20. Id.

21. Id. at 1191-92.

22. See, e.g., id. at 1188; Lascher, Lascher At Large, 52 CAL. ST. B.J. 335, 344 (1977). 
may leave the lawyers and lower courts without guidance as to what the supreme court considers the law to be, the alternative of straight denial may leave them with a published decision, citable as precedent and binding upon the trial courts, that stands for what the court considers the law is not. In terms of providing guidance for the development of the law, the alternative of depublication is clearly preferable.

\section{The Right to a Reasoned Judgment}

I suppose there may be some psychological validity to the argument that the losimg party may feel deprived of a valid judgment when the opinion supporting it has been ordered depublished. However, I have difficulty beheving that a client who loses in the court of appeal will feel additionally aggrieved if that court's opinion is depublished. It is at least equally possible, I would think, that he would feel somewhat vindicated. In any event, as his attorney will no doubt explain, depublication does not mean that the supreme court necessarily disapproves of the underpinnings of the decision. Nor does it mean that the court considers the outcome to be wrong, just as a straight denial of hearing does not necessarily carry with it the court's imprimatur.

Depublication is inost frequently used when the court considers the result to be correct, but regards a portion of the reasoning to be wrong and misleading. ${ }^{23}$ There are times, to be sure, when the supreme court considers the result to be wrong as well, but that is true also when the court simply denies hearing. The court is not expected to, and cannot, grant a hearing in all cases in which it considers the outcome erroneous. Unless one were to argue that the depublication alternative should be elimmated as a means of inducing the supreme court to grant hearing in a greater number of cases-and I have yet to hear anyone make that argument seriously-I see nothing additionally improper in the use of depublication orders in such situations.

\section{Secrecy}

Nor do I find a great deal of objective merit in the more generalized criticisn that there is soinething inappropriately secretive about the depublication process. Depublished opinions are not shredded into oblivion after all; copies are available for public examimation, and for analysis and comment by persons interested in the process. ${ }^{24}$ Often, these opinions are preserved for posterity in unofficial reporting systems that serve specialized segments of the bar. The only consequence of a depublication order is that the opinion is not published in the Offi-

23. See Note, supra note 1, at 1185 n.20 (quoting letter from former Chief Justice Wright).

24. Evidence of the accessibility of depublished opinions is anply provided by their collection in Note, supra note 1, at 1200-06, and Biggs, supra note 1, at 1594-96. 
cial Reports, and is therefore not citable as precedent. ${ }^{25}$ The same is true, of course, of eighty to ninety percent of the court of appeal opinions, which that court considers do not meet the criteria for publication. ${ }^{26}$

Having said all this, I must acknowledge that I share with the critics a sense of discomfort about the process. Depublication is a "stronger" alternative than straight denial. It not only elimmates the court of appeal opinion as precedent, but it also removes that opinion from the realm of judicial discourse, and therefore from the development of the common law. If there are potentially practical alternatives to the present practice of ordering depublication without explanation, they deserve to be exammed with care.

III

\section{Alternatives to the Depublication Procedure}

In my view, certain of the procedural suggestions to improve the decertification process have considerable merit. For example, I can thmk of no valid reason, if the practice is to continue, why depublication should not be supported by an express rule of court that acknowledges the existence of the option and states in general terms the occasions for its exercise. Such a rule would help to legitimize and demystify the practice in the eyes of practitioners and the public. Such a rule could also address the concerns that have been expressed regarding the procedures by which the option is implemented-the problems of public notice and the status of an appellate opinion pending action on a decertification request. ${ }^{27}$ The adoption of such a rule would not, however, satisfy the more substantive concern that depublication, or at least depublication without commentary, is simply an unacceptable means of shaping the law.

25. Opinions by the court of appeal that are not published may not "be cited or relied on by a court or a party in any other action or proceeding . . ." CAL. CT. R. 977(a). Thus, a depublished opinion is unavailable as precedent. E.g., Powers v. Sissoev, 39 Cal. App. 3d 865, 872 n.8, 114 Cal. Rptr. 868, 873 n.8 (1974).

26. See supra note 2 . In 1981-82 only $12.6 \%$ of all court of appeal majority opinions were published. 1983 Jud. Council Cal. ANN. Rep. 94.

27. As I have noted, very few decertification orders are made absent a petition for hearing. See supra note 1 . Where such requests do not accompany a petition for hearing, the party requesting decertification should, as a matter of professional courtesy, serve the request on all interested parties. Inasmuch as such requests are not acted upon immediately, there would be an opportunity for those opposing the request to make their views known to the court. Some requirement of notice to all parties could be incorporated into a depublication rule.

Even under the present procedure, the precedential status of a decertified opinion prior to publication of the bound volume from which it is deleted can easily be verified. One need only refer to the Cumulative Subsequent History Table at the end of each volume of the Official Reports. 


\section{A. Depublication with a Statement of Reasons}

One alternative to the current depublication practice is to permit depubhication to continue, but to require the court to include in its decertification orders a statement of "specific reasons for decertifying," with a special designation of errors in criminal and constitutional cases. ${ }^{28}$ Under this proposal, the published opinion would not be citable as precedent until hearing had been denied or the time for appeal had elapsed, ${ }^{29}$ and the decertification order would itself be citable as "indicative of the general thinking of the court." 30 If a specification of reasons means simply a statement that a majority of the court finds some error in the appellate opimion likely to cause confusion in the development of the law, such a statement can easily be made. In fact, it can be inade in a rule authorizmg depublication under such circumstances, so that the court need only refer to the rule. But such a statement would do little to remedy the defects of which critics have complained.

If, however, specification of reasons ineans a brief critique of the court of appeal's opinion, I see several problems. Agreement upon such a statement would impose a substantial burden upon the supreme court's already overtaxed screening process. It is difficult enough to pass intelligently upon 150 items at a screening conference. I fear that to reach consensus upon a statement of reasons for depublication would be a heroic feat in such a short time. The attempt would be provocative, most likely, of dissenting and concurring views. Moreover, it seems difficult to justify the burden in terms of benefit. The court's statement of reasons would be of little value to anyone without the opinion under critique. Thus, as a depublished opinion cannot be cited as authority, citation of the depublication order would likely be of little value. Finally, such a procedure would do nothing to correct the perceived problem of the losing litigant in search of a reasoned explanation for his defeat.

\section{B. Statement Accompanying a Denial of Hearing}

In 1979, a coinunittee appointed by Chief Justice Bird to review the selective publication system reached a severe conclusion regarding depublication. ${ }^{31}$ In the committee's view, depublication, as a "distinct form of substantive review" was "undesirable and should be brought to an end" by a rule precluding decertification except for failure of the

28. Note, supra note 1 , at 1194-96.

29. Id. at 1195 n.65.

30. Id. at 1197.

31. Report of the Chief Justice's Advisory Committee for an Effective PublicaTION RULE, June 1, 1979. 
opinion to meet the specified standards for publication. ${ }^{32}$ In its place, the committee recommended that the court revive its former practice of "withholding approval from erroneous portions of court of appeal opinions on denial of hearings." 33

This suggestion echoes a practice that the supreme court engaged in, sporadically, for some four decades, finally abandoning it altogether in the mid-1940's. ${ }^{34}$ The court from time to time used a variety of verbal formulae: in soine cases it "withheld its approval" of all or part of the opinion; in others it "disapproved" or "approved" part of the opinion; in others it "was not to be understood" as approving or disapproving part or all of the opinion; and in still others it simply "expressed no opinion" as to part or all of the opinion. ${ }^{35}$

This practice met with scholarly criticism. Some of this criticisin was based on the unexplained variation in phraseology. Some was based on the ground that any commentary is in conflict with the proposition, first declared in People v. Davis, ${ }^{36}$ and reiterated often thereafter, ${ }^{37}$ that denial of a hearing implies neither approval nor disapproval of the opinion below. ${ }^{38}$ In light of that principle, critics wondered, what did it inean for the court explicitly to "withhold its approval" from a particular opinion? Did it inean that the court in fact disapproved? Or merely that the Davis rule was being applied in the particular case? Or did it mean something in between; for example, that the court doubted the correctness of part or all of the ruling below but was not prepared (or did not clioose) to express its opinion at the time? ${ }^{39}$

To be fair to the committee's proposal, the defects identified with the court's former practice are not necessarily intrinsic to the concept of commentary upon denial. Indeed, as one of the early commentators

32. Id. at 24 (quoting B. Witkin, Manual on Appellate Court Opinions $\S 22$, at 35 (1977)).

33. Id. at 25-26.

34. See B. Witkin, Manual on Appellate Court Opinions § 22, at 36 (1977); Coininent, Courts: Significance of the Practice of the California Supreme Court of Commenting on the Opinion of the District Court of Appeal When Denying A Hearing After Judgment, 28 CALif. L. REv. 81 (1939) [hereinafter cited as Comment, Significance]; Comment, Comments by the Supreme Court on Denial of a Petition for Hearing, 13 S. CAL. L. REv. 461 (1940).

35. Cases from the decade 1928 to 1938 in which the supreme court denied hearing and cominented upon the court of appeal opinion are collected and classified by the commenting language used in Comment, Significance, supra note 34, at 88-91.

36. 147 Cal. 346, 350, 81 P. 718, 720 (1905).

37. See Western Lithograph Co. v. State Bd. of Equalization, 11 Cal. 2d 156, 167-68, 78 P.2d 731, 737 (1938); Shelton v. City of Los Angeles, 206 Cal. 544, 550, 275 P. 421, 424 (1929); People v. Rabe, 202 Cal. 409, 418-19, 261 P. 303, 307 (1927); In re Stevens, 197 Cal. 408, 423-24, 241 P. 88, 94 (1925); Bohn v. Bohn, 164 Cal. 532, 537-38, 129 P. 981, 984 (1913).

38. Counment, Significance, supra note 34, at 82.

39. Id. at 83. 
observed, the confusion might be minimized if the court were to explam, by opinion or rule, precisely what it did mean by a phrase such as "approval withheld."40 Perhaps, as that commentator has suggested, the court could estabhsh that when it "withholds approval" from an opinion, it really is saying:

"Whereas normally we express no views on denial of hearings, and are not to be taken as either approving or disapproving of the opinion below, in this case we think it appropriate to make an exception, and to say that we doubt the soundness of the views expressed by the . . . court of appeal." 41

And, I suppose, the court could take one further step and state that the usual principle of stare decisis as declared in Auto Equity Sales $v$. Superior Court ${ }^{42}$ does not apply to an opinion that bears such an imsignia of doubt.

It is possible that such a comment on denial phraseology would help allay the general concern that there is something unduly secretive about depublication, and to that extent it might serve a beneficial purpose. Such a comment might also prove useful in those cases im which the court has reservations regarding only a portion of the opmion, considering the remainder to provide helpful guidance in an uncharted area of the law. However, this procedure would not give much satisfaction to a losing litigant (much less to the author of the appellate opinion); nor would it offer meaningful guidance as to the supreme court's thinking on the legal principles involved. On the contrary, it could engender additional confusion as to the basis for the court's explicit withholding of approval, and as to the degree of rejection such a statement would iniply. It is likely, I think, that pressures would mount toward articulating more and more precise statements of the court's reasonimg. If attempts at commentary became bogged down in disagreement over how the commentary should be phrased, or in the expression of differing views, the process could quickly exceed the limited time and resources of the court. It inight be desirable to experiment with such a procedure on a limited basis, but I am skeptical about accepting it as a wholesale replacement for depublication orders.

\section{Alternatives to Denial}

An entirely different set of alternatives has on occasion been proposed, aimed at facilitating the disposition of cases through grant and retransfer to the court of appeal, ${ }^{43}$ or through grant of hearing limited

40. See Comment, supra note 14, at 816.

41. Comment, Significance, supra note 34, at 83.

42. 57 Cal. 2d 450, 455, 369 P.2d 937, 939-40, 20 Cal. Rptr. 321, 323-24 (1962).

43. See Comment, supra note 14, at 807-11. 
to specified issues. ${ }^{44}$ Both these alternatives, to the extent that they might avoid denial of hearing, would have the effect of minimizing the occasion for depublication. Both have potential; both have problems.

\section{Grant and Retransfer}

As I have mentioned, the suprenie court rarely retransfers a case to the court of appeal for reconsideration after a written opinion, except "in light of" some authority that either the court of appeal overlooked in its opinion or that was not available to the court of appeal at the time it filed its opinion. ${ }^{45}$ It has been suggested that the suprene court expand its use of the grant and retransfer option: The court should order reconsideration of opinions it would otherwise have ordered depubhished, while giving the appellate court some indication in its retransfer order as to how the supreme court would like to see the case come out the second time. ${ }^{46}$

This suggestion touches upon several rather sensitive aspects of the relationship between the two appellate tribunals. The court of appeal presumably has already considered the matter with care. For the supreme court to send the case back for "reconsideration" in the light of nothing inore than the authorities the intermediate court has already taken imto account seenis a bit highhanded, at least. Suclı a procedure could also prove futile, simce im the absence of clear direction, the court of appeal, as an autonomous court, would be fully free upon reconsideration simply to confirm its earlier decision. While clear direction might be possible in some cases, substantial question exists as to the propriety of having the supreme court order the court of appeal to modify its decision im a particular way ${ }^{47}$ Finally, unless the suprene court believed that the opimion under review reached an erroneous result, there would seem little point to a requirenent that the court of appeal, already overburdened, engage in further proceedings simply to rewrite its opimion in the way a school child might be expected to re-

44. Report of the Chief Justice's Advisory Committee for an EfFective PublicatIon Rule, June 1, 1979, at 6, 27-28; see Comment, The California Supreme Court and Selective Review, 72 CALIF. L. Rev. 720 (1984).

45. See supra note 15 and accompanying text.

46. Comment, supra note 14, at 807-11.

47. The California Constitution, article VI, $\S 12$ provides that the supreme court "may, before decision, transfer a cause from itself to a court of appeal . . . . The court to which a cause is transferred has jurisdiction." The intent of this language is usually taken to mean that the supreme court may either grant a hearing, in which it must decide all issues in the case, or it may, "before [it reaches a] decision," retransfer the case to the sole jurisdiction of the court of appeal.

This was the view taken by Justice Houser of a predecessor to article VI, $\S 12$. In the context of the court's commentary on denial of hearing, Justice Houser maintamed that the court has "neither direct nor implied authority . . to modify an opinion theretofore rendered by a . . . Court of Appeal . . . " Wires v. Litle, 27 Cal. App. 2d 240, 246, 82 P.2d 388, 389 (1938) (Houser, J., concurring). 
write an essay. Such concerns may underlie the supreme court's traditional reluctance to expand the grant and retransfer option.

\section{Selective Review}

That the Supreme Court should be able to exercise its review power selectively, limiting review to specified issues decided by the court of appeal, seems self-evidently appropriate. It is absurd that the highest court in one of the largest states should be required to assume responsibility for deciding every issue in a case simply because there is one issue of sufficient significance to warrant a grant of hearing. The pending proposed constitutional amendment ${ }^{48}$ which would explicitly authorize such selective review, seems eminently desirable. Further, I would predict that such selective review would elimmate the need for depublication in a substantial number of cases. I doubt, however, that it would eliminate the need altogether.

\section{CONCLUSION}

Winston Cluurchill once said of democracy that it is the worst form of government except for all the others. Though I would scarcely liken depublication to democracy, the same logic applies. I am uncomfortable with depublication, mainly because it gives rise to so much misunderstanding, and I favor restraint in its use. In my judgment, other options are worth trying-I would include in that category the selective use of commentary upon denial of hearing-in order that depublication be kept to a minimum. Unquestionably, the court's ability to grant hearings limited to specified issues would prove useful in that regard as well, and other solutions may surface. Meanwhile, if the choices are to grant a hearing or to deny and leave published an opinion that could lead to compounded error, the depublication alternative is preferable, though certainly not ideal.

48. Senate Const. amend. No. 29 (as amended in Senate, Apr. 10, 1984) (introduced by Sen. Watson, Mar. 4, 1983). 